\title{
Wide-field and high-resolution optical imaging for early detection of oral neoplasia
}

\author{
Mark Pierce ${ }^{1 *}$, Kelsey Rosbach', Darren Roblyer ${ }^{1}$, Tim Muldoon$^{1}$, Michelle Williams $^{2}$, Adel El-Naggar $^{2}$, \\ Ann Gillenwater ${ }^{2}$, Rebecca Richards-Kortum ${ }^{1}$ \\ From 2nd Scientific Meeting of the Head and Neck Optical Diagnostics Society \\ San Francisco, CA, USA. 23-24 January 2010
}

Current procedures for oral cancer screening typically involve visual inspection of the entire tissue surface at risk under white light illumination. However, precancerous lesions can be difficult to distinguish from many benign conditions when viewed under these conditions. We incorporated cross-polarization, narrowband reflectance, and fluorescence imaging modes in a portable, robust, wide-field imaging device to reduce specular glare, enhance vascular contrast, and detect diseaserelated alterations in tissue autofluorescence.

We have also developed a portable system to enable high-resolution evaluation of cellular features within the oral mucosa in situ. This system is essentially a widefield epi-fluorescence microscope coupled to a $1 \mathrm{~mm}$ diameter, flexible fiber-optic imaging bundle, capable of imaging nuclear size and nuclear-to-cytoplasmic ratio following topical application of a fluorescent labeling solution. Proflavine solution was used to specifically label cell nuclei, enabling the characteristic differences in N/C ratio and nuclear distribution between normal (b) and cancerous (d) oral mucosa to be quantified. This presentation will discuss the technical design and performance characteristics of these complementary imaging systems. We will also present data from ongoing clinical studies aimed at evaluating diagnostic performance of these systems for detection of oral neoplasia in high- and low-prevalence populations.

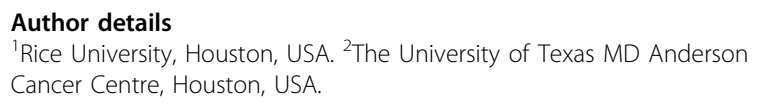

${ }^{1}$ Rice University, Houston, USA

Full list of author information is available at the end of the article
Published: 29 October 2010

doi:10.1186/1758-3284-2-S1-02

Cite this article as: Pierce et al:: Wide-field and high-resolution optical imaging for early detection of oral neoplasia. Head \& Neck Oncology 2010 2(Suppl 1):O2.
Submit your next manuscript to BioMed Central and take full advantage of:

- Convenient online submission

- Thorough peer review

- No space constraints or color figure charges

- Immediate publication on acceptance

- Inclusion in PubMed, CAS, Scopus and Google Scholar

- Research which is freely available for redistribution

Submit your manuscript at www.biomedcentral.com/submit
C Biomed Central 